The Henbury craters show an irregular distribution within an area of half a mile square. The three larger ones are adjacent, and the largest measures 220 by 120 yards across, with a depth of 50 to 60 feet. The others are approximately circular in outline, with diameters ranging from 10 to 80 yards. Owing to the craters acting as collecting pans for rain-water in this arid region, the spots are marked by the growth of mulga trees, acacias, and coarse grass. This helps to locate the craters, which with their gently sloping outer surfaces are not very conspicuous until the interior is viewed from the edge of the rim. Radiating outwards from some of the craters into the plain are five or six low ridges of sandstone, which may have some relation to the percussion of the meteorites. The steep inner walls of the craters consist of powdered rock and shattered blocks of sandstone, quartzite, and slate. The masses of iron found scattered around these craters range from a fraction of an ounce to $170 \frac{1}{2} \mathrm{lb}$. in weight. In one area of 6 feet by 6 feet more than a hundred pieces were collected. Many of the smaller pieces are flaky and shell-like, and are probably the result of the breaking down of larger masses by weathering. Laminated 'ironshale 'in pieces up to several pounds in weight has been found in association with the irons, and it is evident that this has resulted by oxidation of the iron. As at the Meteor Crater in Arizona, it is remarkable that very little meteoritic material has been found within the crater-walls. Here only two pieces of iron have been found inside one of the craters; and in one of the smaller craters a borehole through fine silt down to coarse rock fragments at a depth of 8 feet yielded no mass of iron. Outside the craters were found some fragments of scoriaceous glassy material, which in micro-sections is seen to consist of silica-glass impregnated with iron oxide. This resembles the Arizona material, and was no doubt formed by the fusion of the sandstone by the impact of the meteorite.

At Henbury, with the numerous masses of iron scattered around several craters, there must have been not a single meteorite, but a shower. Further exploration of the locality is to be made this year, and it is hoped that more data will then be available. In the meantime any speculation on the mechanics of the formation of such craters must involve many assumptions. Mr. Alderman is of the opinion that the craters were formed ages ago, while $\mathrm{Mr}$. Bedford believes that they are comparatively recent. The latter mentions that the old blacks will not camp near the place, and that they call it " chindu chinna waru chingi yabu", meaning "sun walk fire devil rock" ; which suggests that the natives have some tradition of the fall.

\title{
Implements of Chinese Fossil Man
}

$\mathrm{T}^{\mathrm{H}}$ HE scientific reports on the discovery of implements and remains of fires in association with the fossil man Sinanthropus have now been published by the Geological Society of China.* It is therefore possible to appreciate the significance of this addition to our knowledge of one of the earliest representatives of the human race. There are no traces of glacial or pluvial episodes in the superficial deposits of eastern China to mark horizons; but the distribution of the fossil mam. mals seems to show that Sinanthropus is of Lower Pleistocene age. $\dagger$

The disintegrated charcoal from wood fires occurs abundantly in old hearths resembling those which are now familiar in the Palæolithic settlements of Europe. In one place it is scattered throughout a deposit seven metres thick, and Prof. Breuil remarks that the fire was probably replenished continuously during the long period which is represented by so great a thickness of residue. Among the charred remains are numerous burnt bones and stones, including implements. Deer antlers were cut into short lengths by flakes of stone, aided by burning at the lines of section. The bases of antlers seem to have been used as hammers. The

*D. Black, "Evidences of the Use of Fire by Sinanthropus", Bull. Geol. Soc. China, vol. 11, pp. 107, 108; 1931. H. Breuil, "Le Feu et I'Industrie Lithique et Osseuse a Choukoutien", tom. cit., pp. 147-154 (also in L'Anthropologie, vol. 42, pp. 1-17; 1932). W. C. Pei, "Notice of the Discovery of Quartz and other Stone Artifacts in the Lower Pleistocene Hominid-bearing Sediments of the Choukoutien Cave Deposit", tom. cit., pp. 109-139, pls. i-iii.

Deposit", tom. "it., pp. 109-139, pls, i-iii. $\dagger$ W. C. Pei, "The Age of Choukoutien Fossiliferous Deposit", Bull.
Geol. Soc. China, vol. 10, pp. 165-178; 1931. C. C. Young, "Die Stratigraphische und Palaeontologische Bedeutung der fossilen Nagetiere Chinas", tom. cit., pp. 159-164, with 3 tables.

No. 3265, VoL. 129] young antler fixed to a piece of skull was used whole, the base being trimmed for a convenient handle. Bits of brain-case seem to have been made into cups; some of the upper jaws were evidently used as files, and some of the lower jaws as small picks, with the coronoid process as working tip. The long bones were regularly broken for the marrow, and some of them seem to have lost only one end, where a stone would be fixed as in a handle.

The stone implements are rudely made of flakes which have been taken from stones found in the river below, and from quartz which occurs on the opposite side of the valley. They are well described by $\mathrm{Mr}$. Pei, and are illustrated with both photographs and diagrams. They are all small, the largest not more than $15 \mathrm{~cm}$. in greatest diameter, and they are at least as varied in shape as the implements met with in the Mousterian deposits of Europe. There are cores and flakes, showing that the implements were made on the spot, and some of the cores themselves are retouched for use.

As the Choukoutien deposits obviously represent a human dwelling-place, while the only remains of Sinanthropus hitherto discovered in them are skulls and jaws, Prof. Breuil discusses the suggested possibility, that the fires and implements were made by a higher type of man who collected the skulls of a lower race as trophies of the hunt. He wisely rejects this suggestion, and looks forward to the discovery of numerous still more primitive ancestral men with real human intelligence. 
Piltdown man (Eoanthropus) is at least as old as Sinanthropus, if not older, and was shown long ago by Mr. Charles Dawson and myself to have made both stone and bone implements, and to have split bones, doubtless for extracting the marrow. More recently, burnt flints have been noticed in the Piltdown gravel, and not long ago I found one such flint which is indistinguishable from the 'pot boilers' of later periods. The beginning of human arts, indeed, dates back to immense antiquity, before man had assumed his present form.

A. SMITH Woodward.

\section{Obituary}

Sir William Watson Cheyne, Bt., F.R.S. $\mathrm{IN}$ spreading the doctrines and technique of 1 antiseptic surgery, Joseph Lister had no more efficient nor more ardent disciple than William Watson Cheyne, who died, after a long illness, on April 19 last, in the eightieth year of his age. From very humble beginnings, Cheyne, by sheer ability, perseverance, and high principle, reached the summit of the surgical profession in Great Britain and commanded the respect of the whole medical world.

Not only was Cheyne a practical operating surgeon, but under the influence of Lister he was also a pioneer of bacteriological research in England, and did more than anyone else to diffuse the bacteriological knowledge which in the seventies and eighties of last century had accumulated at an astonishing rate in Germany and France. In this advance, England played almost no part, if we except Lister himself. At first we concerned ourselves with research in histology and physiology, and at a later period the energy of English workers was directed by the writings of Virchow and the growth of the cellular pathology. We had not learned the snares of bacteriological technique, and even Lister himself, working alone and with imperfect methods, fell into bacteriological errors which, however, he later handsomely admitted and corrected. Watson Cheyne was closely associated with Lister, and although he did not publish many separate memoirs on bacteria, he incorporated much original research in his surgical works and particularly in his "Antiseptic Surgery, its Principles, Practice, History, and Results ", 1882, pp. 616.

Cheyne also did much to introduce English students to bacteriology by his translation of the second edition of Flügge's famous " Fermente und Microparasiten". This translation was published in $\mathbf{1 8 9 0}$ by the New Sydenham Society under the title "Micro-organisms with Special Reference to the Etiology of the Infective Processes ", and ran to 826 pages. Cheyne also edited an important collection of classical bacteriological papers under the title "Recent Essays by Various Authors on Bacteria in Relation to Disease", 1886. By these works Cheyne became widely known, but at a relatively early date he was forced to relinquish his scientific work as he had to earn his living. In those days there were no whole-time paid pathological-far less bacteriological-posts in the country except in the four Scots universities. Cheyne therefore took up surgery as a practical profession, but he continued to be a voluminous writer, and most of his writing was of high medical quality. One of his chief works was that in conjunction with F. F. Burghard, and entitled "A Manual of Surgical Treatment". second edition, 5 vols., 1912-1913. For many a day this was a standard work.

As a spectacular operator, Watson Cheyne could not be classed alongside several surgeons even in his own day, but he did all his work in the most conscientious way, and the welfare of his patient was his first and last concern. He thus early acquired a name for surgical rectitude, and his opinion and skill were soon in such demand that he acquired a very large practice, and for many years led an exceedingly busy and useful life. Lister's mantle may be said to have fallen upon Watson Cheyne, who bore it nobly and well, and the pupil was a credit to the great founder of the antiseptic principle in surgery.

Sir William Watson Cheyne was born-at sea it is said - on Dec. 14, 1852, the son of Andrew Cheyne and his wife Eliza, daughter of the Rev. William Watson, minister of the far-away island of Fetlar in Shetland, and in the manse of this wind-swept island Cheyne spent his boyhood and learned to love the sea. He always visited Shetland whenever he could, and after the Sturm und Drang of a long professional and busy life in cities, he retired to the Ultima Thule where he had spent so many happy years, and settled once more in Fetlar until a year or two before he died.

Cheyne studied medicine in Edinburgh and graduated M.B., C.M. there in 1875 . He then went to Vienna and Strassburg, and thereafter he became house surgeon to Joseph Lister, at that time professor of clinical surgery in Edinburgh, and nearing the height of his fame. When, in 1877, Lister was invited to take up the duties of surgeon at King's College, London, he asked Cheyne to accompany him to be his first house surgeon. Cheyne took the F.R.C.S. diploma in 1879, and in due course was elected assistant surgeon at King's College Hospital. He finally reached the position of consulting surgeon and retired.

When the South African War broke out Sir William at once volunteered for active service and was appointed a civil consulting surgeon. In the War of 1914-1918 he was at first Consulting Surgeon to the Royal Navy and, later, Surgeon-General, R.N. Finally, in 1918, he attained the rank of Surgeon Rear Admiral. He was created baronet on July 20, 1908, and was appointed Surgeon-inOrdinary to H.M. the King. In 1914 he was elected president of the Royal College of Surgeons, and he was the first recipient of the Lister Memorial Medal in recognition of his distinguished contributions to surgical science. Retiring from practice, he was 